THURSDAY, NOVEMBER I3, 1873

\section{ON THE MEDICAL CURRICULUM}

$\mathrm{N}$ a recent number of this journal (NATURE, Oct. 2, r873) we made some remarks on medical studies, which were intended more for students themselves than in any way to bear on the principles of medical education. To the latter subject special attention has just been directed by Prof. Huxley, who, as Lord Rector of the University of Aberdeen, has drawn up a series of propositions for the consideration of the Court at the next meeting in February or March, on which occasion he will deliver his inaugural address.

The following are the motions that the Lord Rector will propose :-

" $I$. That, in view of the amount and diversity of the knowledge which must be acquired by the student who aspires to become a properly qualified graduate in medicine; of the need recognised by all earnest teachers and students for the devotion of much time to practical discipline in the sciences of chemistry, anatomy, physiology, therapeutics, and pathology, which constitute the foundation of all rational medical practice ; and of the relatively short period over which the medical curriculum extends-it is desirable to relieve that curriculum of everything which does not directly tend to prepare the student for the discharge of those highly responsible duties, his fitness for the performance of which is certified to the public by the diploma granted by the University.

"II. That it would be of great service to the student of medicine to have obtained, in the course of his preliminary education, a practical acquaintance with the methods and leading facts of the sciences comprehended by botany and natural history in the medical curriculum; but that, as the medical curriculum is at present arranged, the attendance of lectures upon, and the passing of examinations in, these subjects occupy time and energy which he has no right to withdraw from work which tends more directly to his proficiency in medicine.

"III. That it is desirable to revoke or alter ordinance No. 16 , in so far as it requires a candidate for a degree in medicine to pass an examination in botany and zoology as part of the professional examination; and to provide, in lieu thereof, that the examination on these subjects shall, as far as possible, take place before the candidate has entered upon his medical curriculum.

"IV. That it is desirable to revoke or alter said ordinance No. 16 , in so far as it requires candidates for the degree of doctor of medicine to have passed an examination in Greek, and that, in lieu thereof, either German or French be made a compulsory subject of examination for said degree, Greek remaining as one of the optional subjects."

In considering these points a review of the method by which the present position of the medical curriculum has been arrived at, will throw considerable light on the steps which ought to be taken for its improvement, and will show how subjects which have but an indirect bearing, or none at all, on medicine proper have been gradually made to form an element of the course of study, without any question having been asked as to whether their introduction does not bring its concomitant disadvantages.

The influence of Materia Medica seems to have been great in bringing about the present state of affairs. When Dr. Anthony Todd Thomson and Dr. Pereira, in their enthusiasm for their favourite subject, extended its limits

VOL, IX, -No. $21 \mathrm{I}$ so as to include a full account of the source and history of every one of the articles which were mentioned in the Pharmacopœia, and went so far as to give a full description of Gallus bankiva, together with all the steps in the development of its egg, simply because Ovi vitellus is an antidote against poisoning by corrosive sublimate, and is employed in the preparation of Mistura Spiritus Vini Gallici (egg flip), it is evident that as the sciences of zoology and botany became more profound, Materia Medica as a subject would proportionately expand. At last a time came when separate lectures had to be given on the above-mentioned kindred subjects, in order that those on Materia Medica might be more easily comprehended by the student; and, as might be expected, these independent lectures on zoology and botany, as those on chemistry had done before, became so complete in themselves, as to reduce the subject which had given rise to their introduction, to a simple formulary for the chemist, with references to the sources of the necessary scientific information. The introduction, however, of zoology and botany as separate independent elements of the curriculum, brought into the medical education a large mass of matter, which is very valuable no doubt in itself, but to the student entirely irrelevant; and as in the short pupilage of three or four years there is a much larger amount that ought to be learned than can be properly acquired in the time, it becomes a matter worth serious consideration, whether subjects which are not indispensable to a thorough training should be still taught and be required by the examining bodies. The question therefore resolves itself into the determination of whether the loss of time necessary for obtaining a superficial knowledge of a couple of sciences, is counteracted by the advantages of those sciences as a mental training and a basis for higher work? In an Introductory Lecture delivered some time ago at University College, Prof. Huxley throws the weight of his opinion in the scale against retaining the subjects which must be to him most dear, in the medical curriculum; and most will agree with him, notwithstanding the many difficulties in the way of an improved programme.

With regard to Prof. Huxley's fourth proposition, in which it is considered desirable to omit Greek from the preliminary examination, and substitute German or French in its place, the interest will not be so great to most, as that relating to the scientific qualifications that are necessary. The same conservative spirit which has prevented any reduction in the overloaded Biological portion of the curriculum, has, without question of any kind being asked, never even hinted at any change in the long-established and well-tried school-course, in which the at one time practically valuable and indispensable Greek and Latin are still retained, though of less importance at the present day. How many of our scientific men find that nothing deters them in every step of their work, more than a want of knowledge of the German language, now that the scientific activity of that country is so considerable and so rapidly increasing. There must be a change with the times, even in primary education, and we hardly think that in his introductory address to the King's College Medical Society on the 23 rd of last month, Prof. Curnow put the case fairly when he disapproved of the substitution of German for Greek, because the one could be 
mastered by a few months' residence in a neighbouring country, whilst the other had done more to develop true culture than almost all other writings since. It is not proposed simply to substitute German or French for Greek, the advantages to be derived from which are now fully absorbed into the spirit of the nation, but, by the change, to leave a sufficient time, in addition to the education in modern languages, for the study of the Natural Sciences during the school-boy period. That the dead languages form an excellent mental training no one doubts, but that Physics and Chemistry do the same is daily becoming more certain; and the time is not far hence when the facts and methods of Physiology and Comparative Anatomy will be so well known and assorted, that they may be placed in the same category.

\section{THE SOUTHERN UPLANDS OF SCOTLAND*}

THE range of hills, which in Scotland extends from 1 the German Ocean to the Irish Sea, having a N.E. and S.W. direction, has been aptly designated the Southern Uplands. This range is nearly parallel in its course to that of the Highlands proper. It exhibits hills, some of which attain to an elevation approaching nearly 3,000 feet; but its physical features, although marked in many localities with scenes of great beauty, are devoid of the stern and rugged grandeur which characterises the more northerly mountains of Scotland. The hills of this range usually consist of rounded and grass-covered undulations, or long tracts of plateaux. They have been specially named the "pastoral district of Scotland," and their scenes have furnished subjects for many a pastoral song, and many a border ballad.

The Southern Uplands of Scotland are cut deeply into by some of the streams which flow into the Solway Firth, the Esk, the Annan, the Nith, the Urr, and the Dee being the most important of them. They are drained on the southward side by the Cree and the Luce ; on the northward side they are the sources of the Ayr; and the Tweed and its rributaries drain a large portion of their north-east area.

In the early period of Scotch geology, the days of Playfair and Hutton, the Southern Uplands were regarded as affording no traces of the evidence of life in the rocks which compose them; and these rocks were referred to the "primary" group. It was not until the discovery of fossils in a limestone which occurs at Wrea in Peeblesshire, in their higher portion, by Sir James Hall, that the rocks which formed these hills were assigned to the "transition" age. The terms "primary" and "transition" have now ceased to be applicable to the nomenclature of geology ; and the discovery by Prof. James Nicol in 1840 , in the flaggy beds of Greiston in Peeblesshire, of graptolites, indicated the Silurian age of the strata here. Since the discovery of $\mathrm{Nicol}$, several geologists have added greatly to our knowledge of the rocks which compose the Southern Uplands. Other bands of graptolites have been found richer in fossil contents than those first discovered ; and these, along with a few other forms of organic remains, have still further confirmed the Silurian age of the

* Memoirs of the Geological Survey of Scotland, Sheets I, 2, 3 and I5, \&c. Explanations of, $1871,1872,1873$; great mass of strata which make up the hilly country in the South of Scotland.

The result of the observations made on the rocks of the Southern Uplands up to the period when they came under the notice of the Geological Survey of Scotland led to the conclusion that the lowest strata exhibited were referable to the Llandeilo age. That these Llandeilo rocks were succeeded by deposits containing fossils, as in the case of the Wrea limestone, indicating the horizon of the Bala or Caradoc rocks, was also known-and certain rocks which occur near the north-western margin of the area in the neighbourhood of Girvan in Ayrshire, have been referred by Sir Roderick Murchison to a still higher position in the Silurian series.

The labours of the Geological Survey of Scotland have not only confirmed these conclusions, but have added greatly to our knowledge of the nature of the Silurian rocks of the South of Scotland. They have also furnished subdivisions of these rocks, and a more ample account of their arrangement and fossil contents.

Every geologist familiar with the lower portions of the Silurian rocks of the Southern Uplands, the Llandeilo strata, had experienced great difficulty in recognising horizons, in this series, such as would enable him to divide these rocks into distinct portions. It is true that bands of anthracitic shale abounding in graptolites were, as regards their petrological nature, very distinct from the rocks in which they were intercalated. The great mass, however, of the Llandeilo beds of the Southern Uplands consist of rocks known in old petrological nomenclature as "greywackes" - a name which is still retained for want of a better-and as these rocks differed only in coarseness, and sometimes in colour, this circumstance rendered the division of the South of Scotland Silurian rocks into separate groups extremely difficult. And when it is added to this that contortions have greatly folded and denudations have largely planed off the edges of these rocks, the difficulty of making out distinct horizons among the Llandeilo strata of the South of Scotland becomes very apparent. It is only by a careful, continuous, and long series of observations recorded in maps large enough to show all the contortions, the ins and outs of the strata, that these rocks could be brought into subdivisions enabling them to be recognised. Such have been the work of the officers of the Geological Survey of Scotland; and now we have in the explanatory notes to some of the sheets which have been published, the results of their work recorded, and the subdivision of these Llandeilo rocks indicated.

The explanation to Sheet 15 , published in $187 \mathrm{r}$, which includes, among other matters, a description of the Llandeilo rocks occurring in that portion of the Southern Uplands occupied by the north-west part of Dumfriesshire, the south-west portion of Lanarkshire, and the south-east portion of Ayrshire, contains the results of the labours of the Survey among these rocks. There do not appear, in any portion of the South of Scotland Silurian strata, any rocks which appertain to an age older than the Llandeilo; and these Llandeilo rocks are referable only to the Upper Llandeilo series, the Lower Llandeilo or Shelve rocks of Murchison, the Arenig rocks or Skiddaw slates of Sedgwick, being unknown in the district. This Upper Llandeilo series exhibits itself in the 